

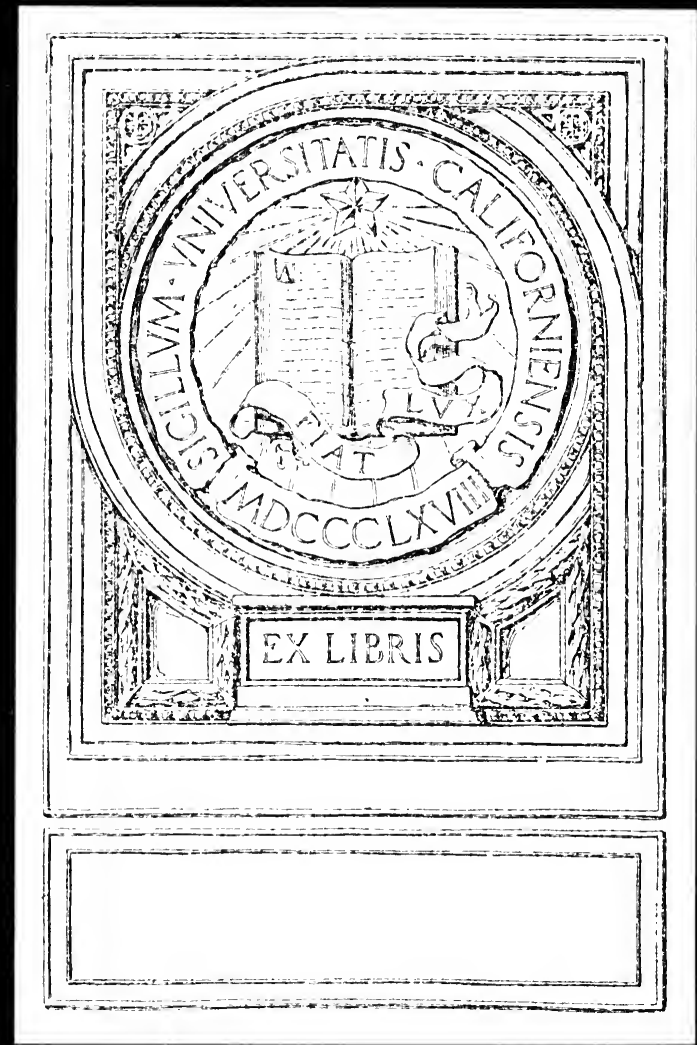




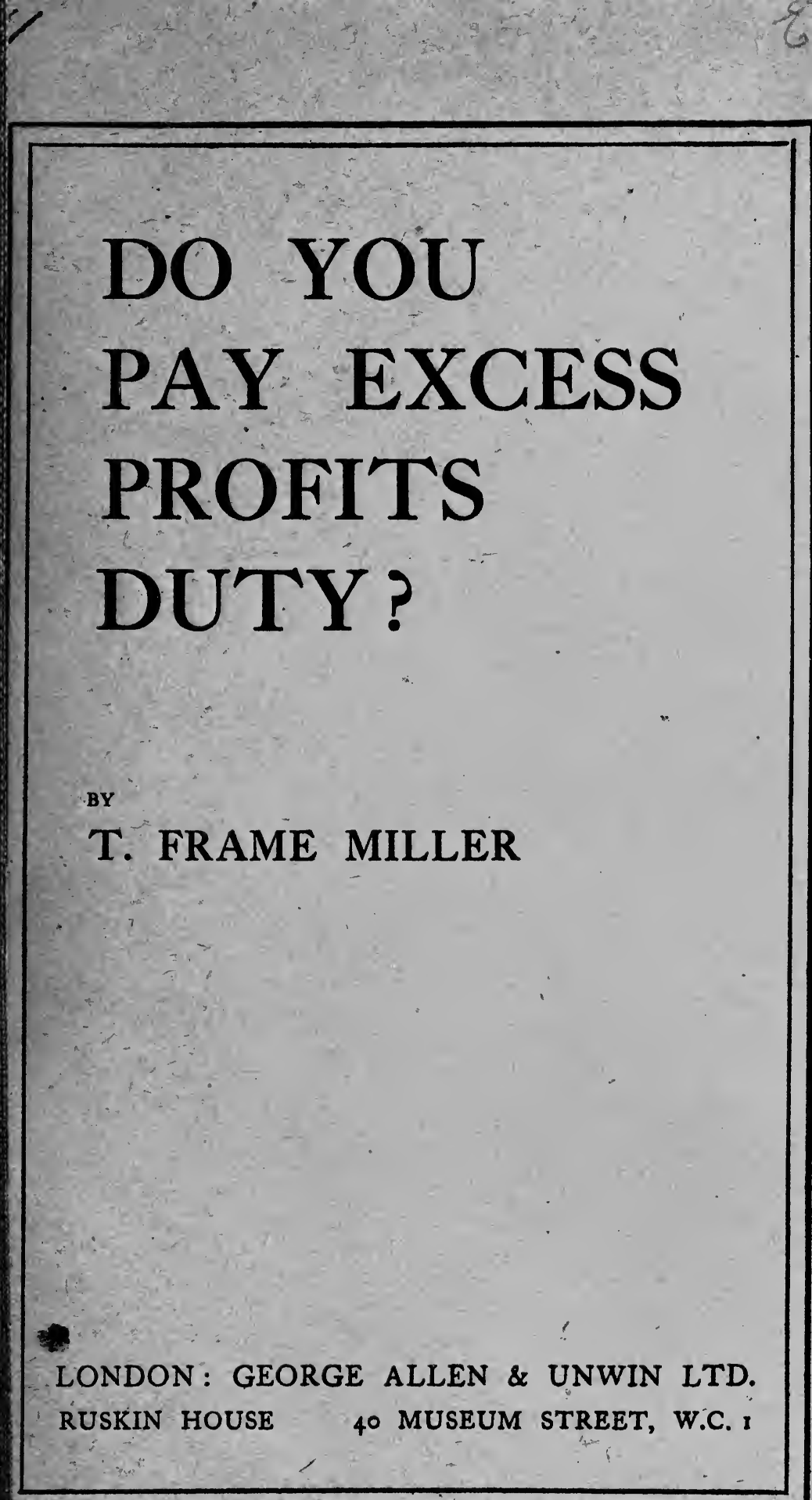




\section{Digitized by the Internet Archive in 2007 with funding from Microsoft Corporation}




\section{DO YOU PAY EXCESS PROFITS DUTY?}

$\mathrm{BY}$

T. FRAME MILLER
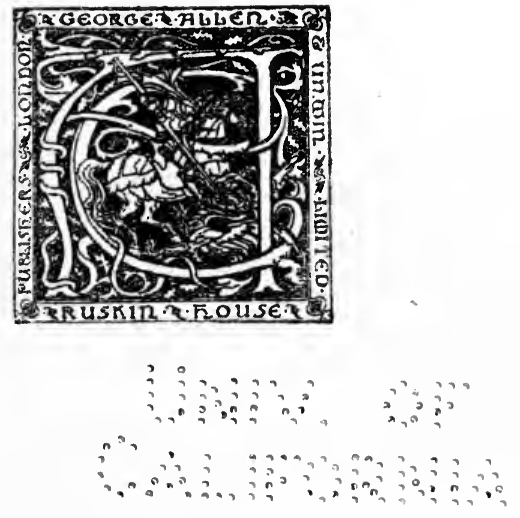

LONDON : GEORGE ALLEN \& UNWIN L'TD. RUSKIN HOUSE 40 MUSEUM STREET, W.C. 


\section{EXCESS PROFITS DUTY CASES.}

\section{Re Directors' Remuneration.}

W. France Fenwick \& Co., Ltd. . . . . 1917 Fellows Ltd. $v$. Corker . . . . . 1917

Re Managers' Remuneration.

Thomson Bros. \& Co. v. Amis . . . . I9I7

W. Hollins \& Co. Ltd. v. Paget . . . . I916

Thomas $v$. Hamlyn \& Co. . . . . . I916

Collette $v$. Lockie, Pemberton \& Co. . . . 1918

Williamson Film Printing Co. . . . . 1918

Re Distinction between Professions and Trades.

Leopold J. Maxse . . . . . . I9I8

North \& Ingram $\quad . \quad$. $\quad . \quad . \quad . \quad$. 1918

Re Husbandry.

Ransom \& Son, Ltd. • . . . . . 1918

First publisfiéd. . Jüly 1918

Second Edition, Fanuary 1919

(All rights reserved) 


\section{PREFACE}

$1 \mathrm{~S}$ the publishers have decided to print a further edition of this booklet, the opportunity has been taken to make one or two alterations in the text of the Articles as they originally appeared in "System." The table of increases in Statutory Percentages granted by the Board of Referees has been revised, and some notes with regard to the valuation of stocks and claims for special depreciation and obsolescence of assets have been added to the Appendix.

Claims for wear and tear and obsolescence of plant and machinery are seldom given the attention they deserve. Generally the taxpayer is satisfied with 5 per cent. on the written-down value of plant and machinery. This, as a rule, is inadequate unless a careful inventory of plant is kept and claims for obsolescence made when they arise.

Apropos the illustration given on page $\mathrm{I} 2$ of liability to Excess Profits Duty arising solely through the alteration in the rates of duty although, in fact, excess profits have not been earned over the whole period. Sir J. Harmood-Banner recently asked the Chancellor of the Exchequer in the House of Commons whether "legislation will be introduced before the final accounting period to adjust the inequalities at present existing; and, if so, in the meantime will he ensure that the Commissioners of Inland Revenue shall defer the collection of Excess Profits Duty from all who suffer from the application of the sections referred to where deficiencies occur, instead of only to those who make application to the Commissioners of Inland Revenue for relief." Mr. Bonar Law's reply was: "No, sir ; the question of introducing legislation on this subject cannot be effectively dealt with until the time comes to consider the measures necessary in connection with the termination of the duty."

6I $\frac{1}{2}$ Fore Street, LondoN.

T. F. M.

E.C. 2 . 


\section{THE FINANCE (No. 2) ACT, 1915.}

\section{Part III.-Excess Profits DutY.}

Charge of Excess Profits Duty.

38.- $r$. THERE shall be charged, levied, and paid on the amount by which the profits arising from any trade or business to which this Part of this Act applies, in any accounting period which ended after the $4^{\text {th }}$ day of August, I9I4, and before the rst day of July, I9I5, exceeded, by more than $f_{200}$, the pre-war standard of profits as defined for the purposes of this Part of this Act, a duty (in this Act referred to as " excess profits duty ") of an amount equal to 50 per cent. of that excess.

2. For the purposes of this Part of this Act the accounting period shall be taken to be the period for which the accounts of the trade or business have been made up, and where the accounts of any trade or business have not been made up for any definite period, or for the period for which they have been usually made up, or a year or more has elapsed without accounts being made up, shall be taken to be such period not being less than six months or more than a year ending on such a date as the Commissioners of Inland Revenue may determine.

Where any accounting period is a period of less than a year this section shall have effect as if there were substituted for $f 200$ a proportionately reduced amount.

3. Where a person proves that in any accounting period, which ended after the 4th day of August, 1914, his profits have not reached the point which involves liability to excess profits duty, or that he has sustained a loss in his trade or business, he shall be entitled to repayment of such amount paid by him as excess profits duty in respect of any previous accounting period, or to set off against any excess profits duty payable by him in respect of any succeeding accounting period, such an amount as will make the total amount of excess profits duty paid by him during the whole period accord with his profits or losses during that period. 


\title{
DO YOU PAY EXCESS PROFITS DUTY?
}

\author{
CHAPTER I
}

The principle of the Duty. The Acts imposing the Duty. Profits Chargeable. Exemptions. Alternative Methods of Computing Excess Profits.

$\mathbf{E}$ XCESS Profits Duty is a war levy. The Chancellor of the Exchequer, at the time of its introduction, said it could only be defended as such, and the duty would be withdrawn as soon as possible after the conclusion of peace. The first Act, imposing the duty at the rate of 50 per cent. on all excess profits, was passed into law on Christmas Eve, I9I5. The duty was continued in IgI6, when the rate increased to 60 per cent., and again in I9I7, when the rate was still futher increased, and is now 80 per cent. of all excess profits.

The majority of business men gladly pay the duty when they earn excess profits. At the same time, as the duty has to be paid in cash at a time when more capital than usual is required, they are anxious to see that they are not over-assessed. Moreover, they must bear in mind the post-war position of the business with which they are connected. They do not want to find when peace is declared that they will have to face a time of unprecedented difficulty with no liquid capital at command.

One of the first principles of taxation is that the subject should know with certainty what he has to pay. There are, however, very few business men who can say with certainty how their excess profits were computed. The calculation is so involved that they leave it to their Accountants to settle the matter with the Surveyor of Taxes, and it is safe to say that only in very simple cases do the Accountants and the Surveyor both arrive at the same figure of excess profits independently. This is due to the fact that, although the principle of the duty is simple, its practical application presents many difficulties.

\section{The Principle of the Duty.}

The principle of the duty is that those trades and businesses earning more profits since the outbreak of war are in a special 
position to contribute towards the cost of the defence of the country. It is immaterial whether the profits are attributable to the war or not; the duty is levied with complete impartiality on all profits in excess of those earned in pre-war years beyond the first $f_{200}$, which is exempted from duty. It is, therefore, necessary to compare the profits made in accounting periods ended after August 4, I9I4, with some sort of Pre-War Standard of Profits. If the business has been established for some years a satisfactory profits standard should be available; if a new business, one is perforce obliged to adopt an artificial standard, based on the capital employed.

The whole of the profits of the war period are to be taken as an entity. Therefore, if a liability to duty arises in one period and in the next period the profits do not reach the point which involves liability to duty, or a loss is sustained, repayment may be claimed of some, if not all, of the Excess Profits Duty paid. No doubt Parliament originally intended that where no excess profits were made during the whole period in which the duty was in force no duty should be payable, but owing to the increases in the rate from 50 to 60 and now to 80 per cent. it may happen in some cases that, although no excess profits are earned during the whole period, there will, prima facie, be a liability-in respect of one of the periods.

\section{The Acts Imposing the Duty.}

The whole of the statute law on the subject of Excess Profits Duty is contained in five Acts of Parliament, viz. :-

I. The Finance (No. 2) Act, I9I5, called the Principal Act, Part III, sections 38 to 45 . Duty is levied at the rate of 50 per cent. of all excess profits above $£ 200$. The sections are supplemented by a Fourth Schedule, which is divided into three parts, viz. :-

Part I contains the rules for computing the profits in the War periods, called the "Accounting Periods" (p. 30). Part II the rules for the computation of the profits before the outbreak of war, called the " Pre-War Standard of Profits" (p. 32).

Part III contains the rules for computing the capital employed in the business, both in pre-war years and since (p. 34).

2. The Finance Act, I9I6, Part III, sections 45 to 57 , continues the imposition of the duty and increases the rate to 60 per cent. of all excess profits. 
3. The Finance Act, I9I7, Part III, sections 20 to 28 , again continues the duty and, while it increases the rate to 80 per cent., makes some important amendments of the law as respects accounting periods ending after December 3I, Igr6.

4. Finance Act, I9I8, Part III, sections 34 and 35 .

5. Income Tax Act, I9I8.

\section{Profits Chargeable.}

The duty applies to all trades and businesses carried on in the United Kingdom, or in any other place by persons ordinarily resident here, with very few exceptions. Businesses of an intermittent character come within the scope of the Act, so that concerns of mushroom growth which have been called into existence as a result of the war, and have subsequently been dissolved after realizing large profits, will be brought into charge. Agencies paid by commission are expressly included. (Act of I9I5, s. 39.)

\section{Exemptions from Excess Profits Duty.}

The Exemptions from the Duty are :-

(a) Husbandry in the United Kingdom ;

(b) Offices and employments ;

(c) Professions where little capital is employed ;

(d) Commercial Travellers and Agents whose remuneration consists wholly of a fixed and definite sum not dependent upon the amount of business done or any other contingency. (Act of I9I5, s. 39.)

The line between trades and professions is not very definitely marked, and cases of difficulty occur. When the Bill was in the House of Commons an amendment was moved, on behalf of the Government, in order to make the meaning clearer. It would have made paragraph (c) run: The profession of a barrister, solicitor, doctor, architect, accountant, or any other profession unconnected with the purchase or sale of property or commodities of any description, etc. The amendment was not pressed, but it indicates what was in the mind of the framers of the measure. There are two recent cases on the interpretation of s. 39 (c) viz.: Inland Revenue $v$. Leopold J. Maxse and Inland Revenue $v$. North and Ingram. (King's Bench.)

\section{Methods of Computing Excess Profits.}

The rules for the computation of excess profits are set out in detail in the Fourth Schedule of the Principal Act. As it is 
necessary to compare the profits earned since the outbreak of war with those earned previously, the most important thing is to make sure that the Pre-War Standard of Profits arrived at represents the maximum profits earned before the war. Parliament, being desirous of assisting the taxpayer to do this, has framed the rules so as to give him the option of choosing one of several alternative methods of arriving at a satisfactory Pre-War Standard of Profits. These alternatives are tabulated on p. 9.

The profits have to be ascertained separately, but on the same principles that are applicable to Income Tax, with certain specified exceptions. The accounts need not, however, be made up for the same periods as those used for Income Tax. Profits for Income Tax purposes have been judicially determined in Usher's Wiltshire Brewery Co., Ltd. v. Bruce (IgI4), in the House of Lords, to be commercial profits, subject to the non-deduction of specified expenses, such as those attributable to capital, sums expended in improvements, or losses not connected with or arising out of the trade in question.

In order to ascertain which of the alternative methods of computing the Pre-War Standard of Profits is most advantageous, it is necessary to take the profits as adjusted for Income Tax purposes and deduct those that are allowed. This should, if necessary, be done for six years, so that if the profits of the last three years have been 25 per cent. or more below the average of the preceding three years, the second alternative for an old-established business may be taken advantage of.

Another factor in ascertaining the best pre-war standard is that of capital. Some businesses have quite a large capital, and earn very little on it, so it may be an advantage to take a percentage standard instead of a profits standard.

The term capital, as defined by Part III of the Fourth Schedule is not synonymous with the term capital as applied to a private company or firm or as understood by economists. Capital means the value of the assets employed in a business at a given date, arrived at in accordance with the rules laid down in the Act, and from which have been deducted all liabilities. Consequently, assets represented by reserves of all kinds, and undistributed profits will form part of the capital. Where a business has been converted into a company, and the shares in the company are wholly or mainly held by the person who was the owner of the business, no value is to be attached to the shares so far as they are represented by "goodwill." Mr. Montagu explained in the House of Commons that the object of this provision with regard to goodwill was " to exclude the man who, in forming a company, 


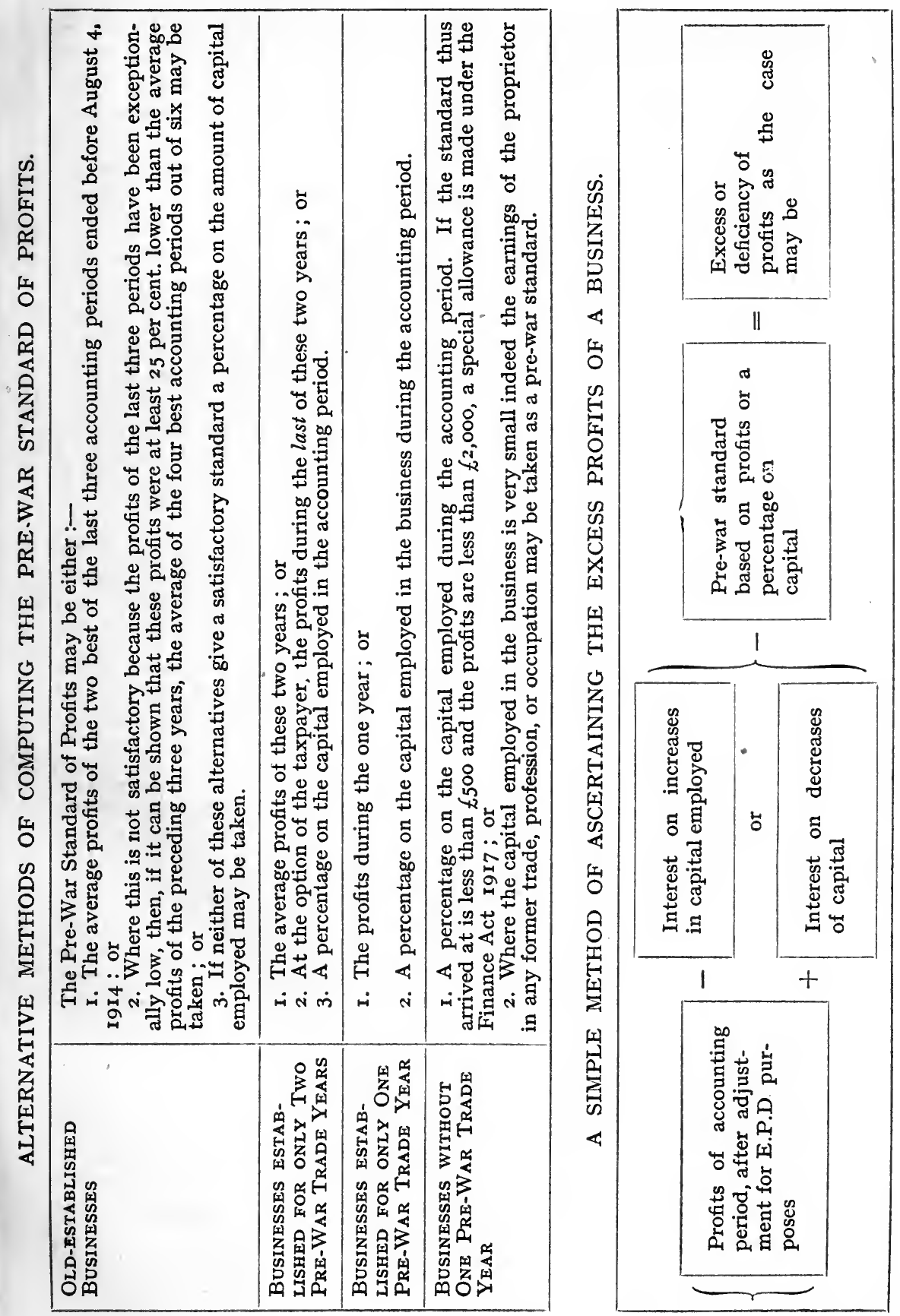


has paid himself for his goodwill by means of an issue of shares to himself." Were it not for this exclusion the proprietor of a business who wanted a high percentage standard would only need to convert his business into a company and assign to himself a large number of shares in payment for goodwill.

The rates allowed in calculating a percentage standard were, down to December 3I, I9I6, 6 per cent. to companies and corporations and 7 per cent. to all others. Now, by section 26 of the Finance Act, I9I7, the rates are increased to 9 per cent. and II per cent. respectively to all businesses without one pre-war trade year in respect of accounting periods ending after January I, I9I7.

The method of arriving at the excess profits of a business may therefore be summarized in accordance with the chart on p. 9 .

The Forthampton Boot Manufacturing Co., Ltd., Profits for the half-year to June 30, 1917, as adjusted for Excess Profits Duty purposes

Deduct 9 per cent. interest on additional capital $\ddot{\ddot{m} p l o y e d}$ as $\ddot{p}$ er

Balance Sheet at December 31, 1916

$$
\begin{aligned}
& \text { Deduct Pre-War Standard of Profits } \quad \ldots \quad \quad \ldots \quad £ 20,000 \\
& \begin{array}{llllr}
\text { Statutory allowance } & \ldots & \ldots & \ldots & 200
\end{array} \\
& £ 20,200
\end{aligned}
$$
months

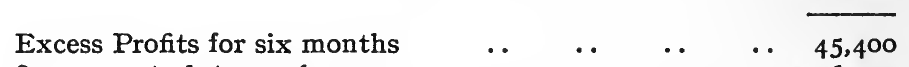

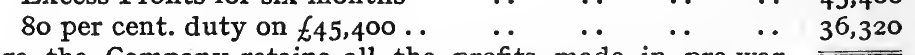

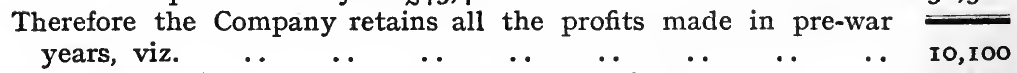

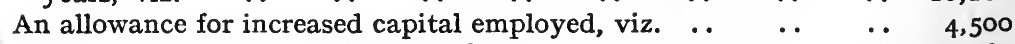

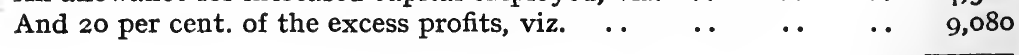

$\begin{array}{rllllll} & 23,680 \\ 36,320 \\ 660,000\end{array}$

For Income Tax purposes where Excess Profits Duty is paid the amount is allowed as a deduction in computing the profits of the year which included the end of the accounting period in respect of which the Duty was paid; but where a repayment is received under section 38 (3), reproduced on page 30 , the amount has to be treated as profit for the year in which the repayment is received. (Income Tax Act, I9I8.) 
Excess Profits Duty a Levy on the excess profits EARNed in the WHOLE PERIOD. How to SELEct THE PRE-WAR StaNdaRd MOST ADVANTAgeous to THE TAXPAYER. SPECIAL RELIEF GRANTED TO THE PROPRIETORS OF SMALL BUSINESSES.

TT is now proposed to give a few illustrations to assist the taxpayer to appreciate the wealth of opportunity given to I. him to select the method best suited to his own particular case.

At the outset it cannot be too clearly understood that the duty is a levy on excess profits earned in the whole period during which the war continues, and for such time afterwards as Parliament considers necessary. Obviously some time must be given to enable people to dispose of stocks bought at inflated prices and to bring the losses sustained into account.

Suppose, for example, the profits of A. T. Rowe \& Sons before the war were $£ I I, 800$ a year, and that since the outbreak of war they have been as follows:-

\begin{tabular}{|c|c|c|c|c|c|c|}
\hline Pro & 10 & ed & be & 1914 & .. & $£$ I 5,000 \\
\hline " & " & " & ", & 1915 & . & 12,000 \\
\hline$"$ & ", & ", & ", & I916 & . & 9,000 \\
\hline ", & ", & ", & " & 1917 & . & 12,000 \\
\hline
\end{tabular}

The profits in the four financial years were $\ldots \quad \ldots \quad £ 48$, 000

The profits earned before the war were $\quad . \quad \ldots \quad$ I I,800

To which has to be added the statutory allowance of . . 200

Making what is called the "Pre-War Standard " of. . £I 2,000

(NoTE.-The profits are assumed to be as adjusted for E.P.D. purposes.)

The total profit the firm is entitled to make in four years without liability to Excess Profits Duty is $£ 12,000 \times 4=£ 48$,000 Therefore, although they had to pay duty on $£ 3,000$ excess profits earned in the twelve months ended September 30, I9I4, the whole of it would be recoverable from the Revenue when the accounts for the twelve months to September 30, I9I6, were available.

Many firms have not earned excess profits until recently, and even now are only liable because the rates of duty have been 
increased. Suppose, the Pre-War Standard is $£ 12,000$; that the Capital remained the same, but the profits earned were distributed thus :-

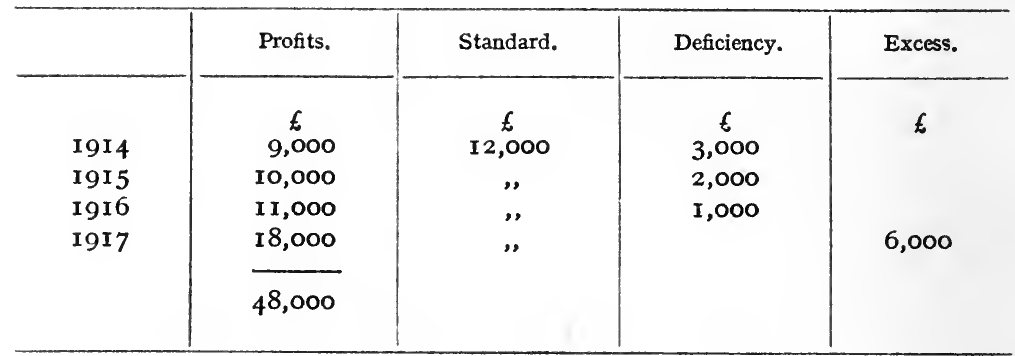

an assessment would be made on the firm as follows:-

Duty of 60 per cent. on $€ \mathbf{I}, 500$, October to December, r916 .. $\quad$.. $\quad 900$ Duty of 80 per cent. on $£ 4,500$, January to September, $1917 \ldots \quad$.. 3,600

Deduct, set-off for deficiencies :-

\begin{tabular}{|c|c|c|c|c|c|c|}
\hline I9I 4,50 per cent. of $£ 3,000$ & . & . & ․ & . & $\stackrel{f}{1,500}$ & $£$ \\
\hline I915,60 per cent. of $£^{2,000}$ & .. & .. & .. & .. & $I, 200$ & \\
\hline 1916,60 per cent. of $£^{1}, 000$ & -. & .. & .. & . & 600 & \\
\hline Duty & .. & . & .. & .. & - & $£ 1,200$ \\
\hline
\end{tabular}

As the liability arises solely through the alteration in the rates of duty and excess profits have not been earned in the four years, the Revenue, it is understood, will not insist upon payment of the $£ \mathrm{I}, 200$, IF APPLICATION IS MADE FOR RELIEF, till a clear liability arises through excess profits being earned in subsequent periods.

Reference to the table of Alternative Methods of Computing the Pre-War Standard of Profits, given on p. 9, shows that the proprietors of established businesses have three alternatives. They may take :-

I. The average profits of the two best of the last three pre-war years; or,

2. The average of the four best years out of six where there has been abnormal depression in trade; or

3. A percentage on the amount of capital employed.

Obviously the higher the Pre-War Standard the less the duty payable will be in the event of the business earning more profit than usual. Therefore, too much care cannot be exercised to ascertain the facts. The Income Tax assessments for six years before the war should be scrutinized; the capital employed 
should be ascertained, and the remuneration of the directors since August, I9I4, should be compared with the sums paid to them in the last pre-war year. Where the profits of two years before the war are similar in amount it will be advantageous to select the year in which similar amount of capital was employed, in order to lower the pre-war average of capital, and so obtain interest on the increases of capital in the war years.

There is one curious point in connection with the third alternative, viz., that where the percentage standard is adopted as the Pre-War Standard of Profits, and the net result of the trading during the last three pre-war trade years was a loss, such net loss may be deducted from the profits earned in the war period. This concession is not granted to those who adopt a profits standard, see Rule 7, page $3 \mathrm{r}$.

The effect of the provision may be illustrated thus :-

The firm of G. W. Bower \& Co. have a capital of $f_{12}, 000$, and earn profits and sustain losses as follows :-

Year ended December 3I, I9II, profit $\quad \ldots \quad \ldots £ 3,000$

\begin{tabular}{|c|c|c|c|c|c|}
\hline$"$ & " & I9I2, loss .. & .. & .. & 2,000 \\
\hline ", & ," & I913, loss .. & . & .. & 1,500 \\
\hline " & ", & I9I4, profit & .. & . & 1,000 \\
\hline ," & ,, & I9I 5, profit & $\ldots$ & .. & 5,000 \\
\hline
\end{tabular}

The percentage standard would be as follows:-

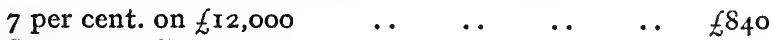

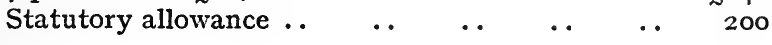

$\overline{£ 1,040}$

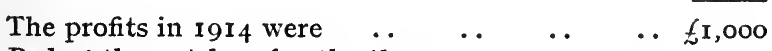

Deduct the net loss for the three years I9II, 1912, and rigr

$$
\cdots \quad \cdots \quad 500
$$

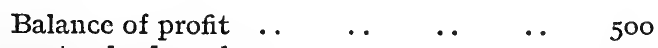

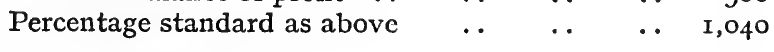

$\begin{array}{lllllll}\text { Deficiency } & . & \ldots & \ldots & \ldots & \ldots & £ 540\end{array}$

Deficiency to carry forward to next year 50 per cent. of $£ 540=£ 270$.

The profits in 1915 were $\quad \ldots \quad \ldots \quad \ldots \quad \ldots \quad \ldots 5,000$

Deduct the percentage standard $\quad . \quad \ldots \quad \ldots \quad \ldots r, 040$

Excess profits $\quad \ldots \quad \ldots \quad \ldots \quad \ldots \quad \ldots 3,960$

Duty 60 per cent. of $£ 3,960$. . $\quad \ldots \quad \ldots \quad \ldots \quad \ldots 2,376$

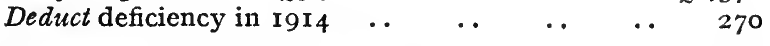

Net amount of duty payable $\quad \ldots \quad \ldots \quad \ldots £ 2,106$ 
It has been assumed that the firm's capital has remained the same throughout.

It is necessary to compute the excess or deficiency for each year separately, as the rates of duty have been increased from 50 to 60 per cent., and now, from January I, I9I7, to 80 per cent. of all profits in excess of the Pre-War Standard.

The factor capital is of great importance now that the percentages allowed on all increases have been raised. Down to December 3I, I9I6, the rates were 6 per cent. for companies and corporations, and 7 per cent. for all others. From January $I$, I9I7, the rates have been increased to 9 per cent. and II per cent. respectively.

The capital employed in a given year can be ascertained from the balance sheet prepared at the end of the previous year. It is important that this should be computed very accurately, not only because the percentage standard is based upon the capital employed, but also because the taxpayer is entitled to a high rate of interest on all increases in the capital. Rule III, which explains exactly how this should be done, is as follows :-

I. The amount of the capital of the trade or business, so far as it does not consist of money, is defined, for the purposes of the Act, in Part III of the Fourth Schedule reproduced in the Appendix.

The rule will be readily understood from the following illustration.

The Forthampton Boot Manufacturing Company had a capital before the war of $f .280,000$. It is desired to ascertain the amount of capital employed in the business in the year IgI6. This can be computed from the figures shown in the balance sheet at December 3I, I9I5.

\section{Forthampton Boot Manufacturing Co., Ltd.}

Balance Sheet-December 31, I9I5.

\begin{tabular}{|c|c|c|c|}
\hline To subscribed capital & $£ 250,000$ & By Goodwill & $t^{150,000}$ \\
\hline " 5 per cent. Debenture & 50,000 & "Freeholds at cost & 100,000 \\
\hline " 4 per cent. Mortgage. & 30,000 & , Plant, less depreciation & 50,000 \\
\hline „, Creditors & 35,000 & "Motors, less depreciatio & 3,000 \\
\hline ", Reserve for depreciatio & & ", Investments at cost & 17,000 \\
\hline of freeholds ... & 40,000 & ", Stock in trade.. & 130,000 \\
\hline General Reserve & 10,000 & ", Debtors, less reserve & \\
\hline Profit for the year & I 10,000 & $£ 3,000$. & 50,000 \\
\hline & & ," Bills receivable & 5,000 \\
\hline & & , Cash balances.. & 20,000 \\
\hline & $£ 5^{25,000}$ & & $£ 525,000$ \\
\hline
\end{tabular}

A dividend at the rate of 30 per cent. was paid on March 31 , 1916, 
COMPUTATION OF CAPITAL EMPLOYED IN THE YEAR I9I6.

Total assets as per Balance Sheet Add Reserve for doubtful debts
.. $\quad . . \quad \ldots \quad \ldots \quad \ldots E 25,000$

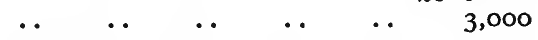

528,000

Deduct-

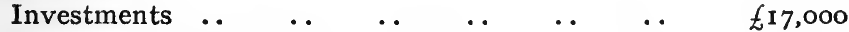

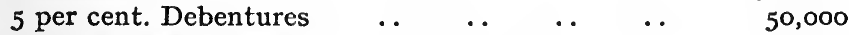

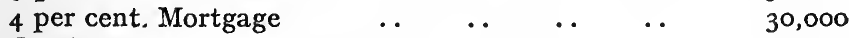

$\begin{array}{llllllll}\text { Creditors } & \ldots & \ldots & \ldots & \ldots & \ldots & \ldots & 35,000\end{array}$

Dividend withdrawn for nine months of the year equivalent to $\quad \ldots \quad$. . $\quad$. $\quad$. . $\quad$..

$$
56,250
$$

I 88,250

339,750

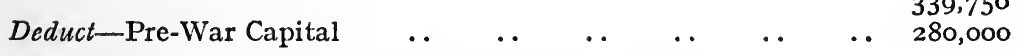

Increase in capital employed upon which interest may be claimed $£ 59,75^{\circ}$

It will be noticed that this method of computing capital is of great advantage to the taxpayer, as the whole of the reserves and undistributed profits are treated as capital on which interest may be claimed. Although investments are excluded this is no hardship, as the dividends received are deducted from the profits.

Where two or more distinct industries are carried on by the same undertaking and proper books are kept, the Commissioners may, where losses were sustained before the war, allow such losses to be disregarded in arriving at the Pre-War Standard of Profit. This is a new concession granted by s. 26, Finance Act, I9I7, and the following will demonstrate the advantage of the provision:-

\section{The Alkalr Company, Ltd.}

Department A.

Year ended Dec. 3I, I9II .. Profit .. £I2,000

Department B.

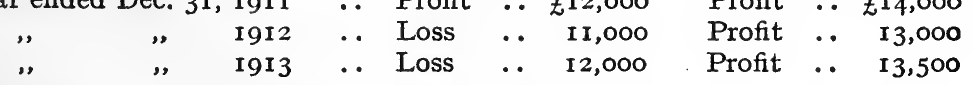

Before the passing of the Finance Act, I9I7, the profits and losses of the two departments would have been amalgamated as follows:-

\begin{tabular}{|c|c|c|c|c|c|c|}
\hline & ofit & .. & -. & • & . & $\ldots £^{26,000}$ \\
\hline 912 & ", & - & . & .. & .. & 2,000 \\
\hline I 3 & ", & .. & . & .. & .. & 1,500 \\
\hline
\end{tabular}

and the Pre-War Standard would have been ascertained thus:-

$\begin{array}{llllllll}\text { I91 r Profit } & \ldots & \ldots & \ldots & \ldots & \ldots & \ldots & £ 26,000 \\ \text { I912 }, & \ldots & \ldots & \ldots & \ldots & \ldots & \ldots & 2,000 \\ & & & & & & & \\ & & & & & & 2 & £ 28,000\end{array}$




\begin{tabular}{|c|c|c|c|c|c|c|}
\hline Allowance & .. & $\cdots$ & $\cdots$ & .. & .. & $\begin{array}{r}{[4,000} \\
200\end{array}$ \\
\hline tandard & . & . & .. & . & .. & $\ell_{14,20}$ \\
\hline
\end{tabular}

The Act allows the following amendment of the standard:-

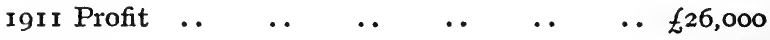

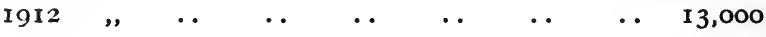

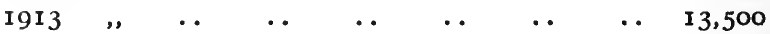

and the Pre-War Standard, instead of being $£ \mathrm{I} 4,200$, will become E19,950, thus:-

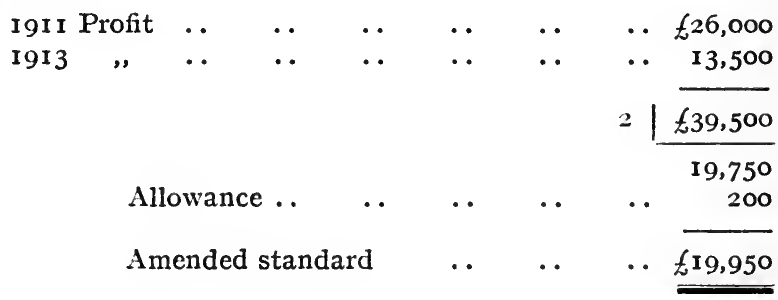

Special Relief to Proprietors of Small Businesses.

I. By Section 26 (4) of the Finance Act, I9I7, an increased measure of relief is granted in the case of small businesses. This provision applies to any accounting period ended after the 3Ist December, I9I6, and its effect is explained below.

2. Under the original provisions of the law relating to Excess Profits Duty, a deduction was allowed at the rate of $£ 200$ per annum in ascertaining the excess profit (or deficiency) of any period of charge and the special relief for which provision is now made will be granted as an addition to that allowance.

3. The full special relief applies in cases where-

(a) The profit of the accounting period is less than $£ 2,000$ (or at a rate less than $£ 2,000$ per annum if the accounting period is less than a year), and

(b) The pre-war standard does not exceed $£ 500$.

The additional allowance to be granted in any such case is one-fifth of the amount by which the profit of the accounting period falls short of $£ 2,000$ (or the proportionate part of $£ 2,000$ where the period is less than a year).

4. The following example will illustrate the operation of the relief :-

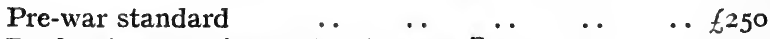

Profit of accounting period (a year) $1 . \quad \ldots \quad \ldots 750$ 
Under the original provisions duty would have been payable on $£ 300$, viz. :-

\begin{tabular}{|c|c|c|c|c|c|c|}
\hline Profit of accounting pe & & $\because$ & *. & . & & $£ 75^{\circ}$ \\
\hline $\begin{array}{l}\text { Less Pre-war standard } \\
\text { Allowance .. }\end{array}$ & .. & 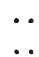 & .. & .. & $\begin{array}{r}£ 250 \\
200\end{array}$ & \\
\hline & & & & & & \\
\hline Chargeable excess & .. & .. & . & - & & 3 \\
\hline
\end{tabular}

Under the present provisions duty is payable on $\AA ⿻_{50}$, viz. :-

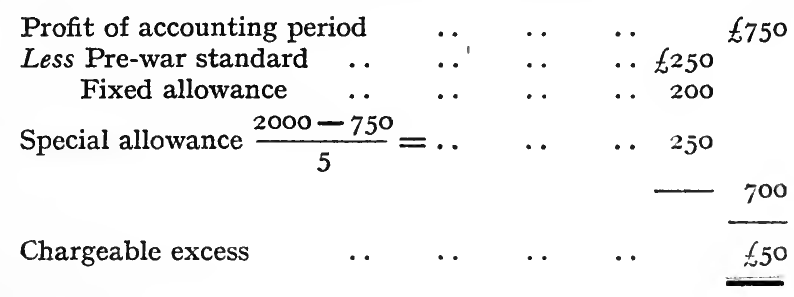

5. The allowance takes the form of a sliding scale whereby the business realizing the smaller profit obtains the greater relief. The maximum allowance is $£ 400$ per annum (in addition to the original fixed allowance of $£ 200$ ), and this maximum is reached when the profit is nil or a loss is suffered. In such cases, while no duty would in any event be payable for the period in which no profit is made, the proposed relief becomes effective by increasing the deficiency which may be set off against the excess profits of earlier or later periods.

6. In the case of a taxpayer whose pre-war standard is somewhat in excess of $£ 500$, a limited form of this relief is given. $\mathrm{He}$ is entitled to any deduction which may be necessary to place him in as favourable a position as if his standard were $£ 500$. For example, if the profits of the accounting period (a year) are $£ \mathrm{I}, 500$ (full special allowance $£$ Ioo), but the standard is $£ 560$ ( $£ 60$ in excess of $f_{500}$ ), the taxpayer is entitled to a reduced special allowance of $£ 40$ ( $£$ IOO $-£ 60$ ) in addition to the fixed allowance of $£ 200$. The maximum relief under the sub-section being $£ 400$ (one-fifth of $£ 2,000)$, this limited relief for taxpayers whose pre-war standard is somewhat in excess of $£ 500$ never applies when the pre-war standard amounts to or exceeds $£ 900(500+£ 400)$.

7. The following table shows the effect of the special relief in a series of cases, the accounting period in each case being taken to be a year. 


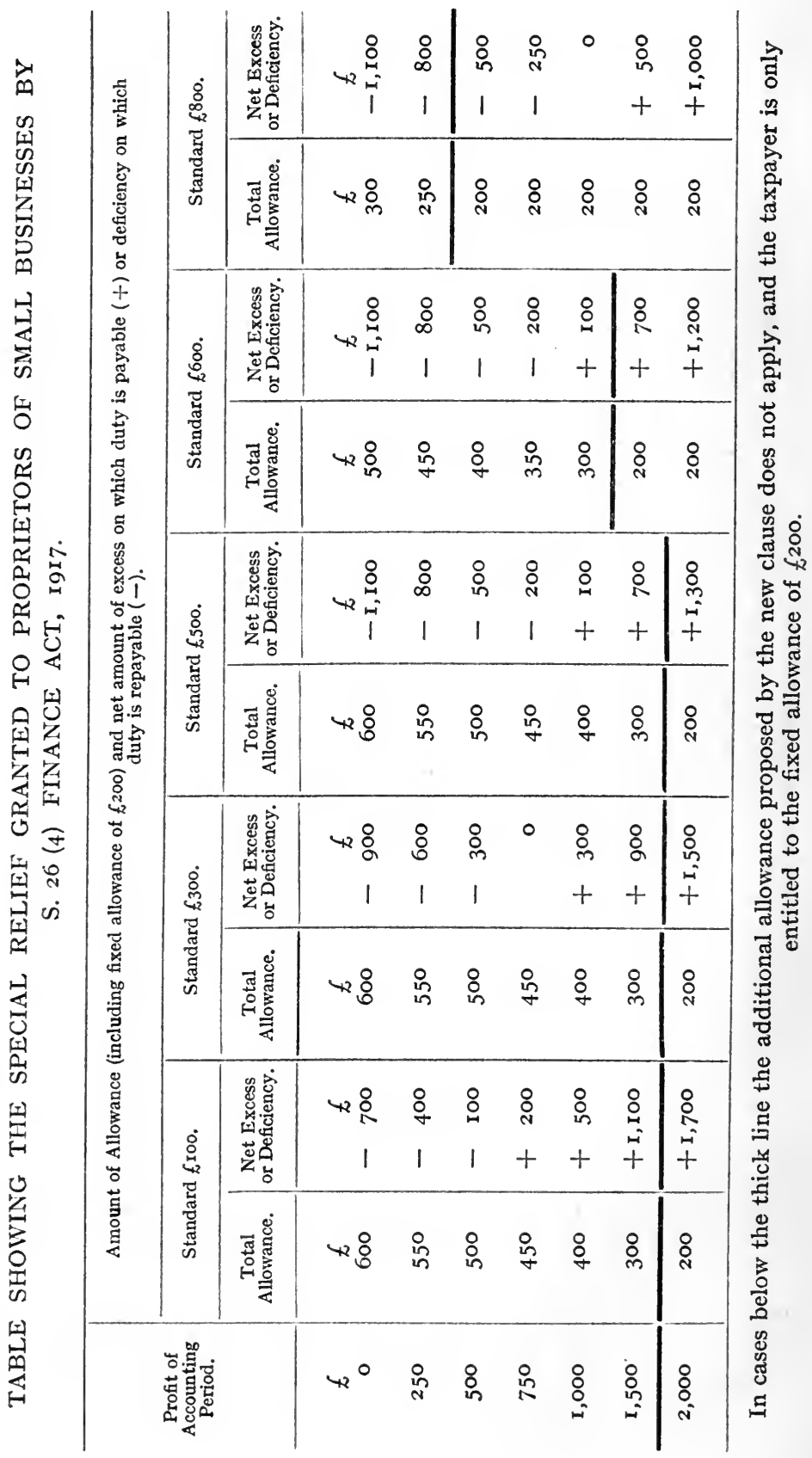




\section{CHAPTER III}

RULES FOR COMPUTING PROFits. COMPUTATION OF the EXCESS PROFits OF (I) A FIRM, (2) A LIMITED COMPANY.

N calculating Excess Profits Duty the first thing to do is to ascertain the "Profits of the Accounting Period, after adjustment for Excess Profits Duty," and the reader is referred to the Fourth Schedule of the Act of 1915, printed in the Appendix, where the Rules are given.

So that the rules may be readily understood, two examples are given, showing exactly how to adjust profits for Excess Profits Duty purposes. It should be observed that (a) the profits of every accounting period are ascertained separately, not averaged as for Income Tax purposes ; and $(b)$ an "accounting period" means any period for which the accounts are made up, not necessarily a year.

\section{COMPUTATION OF THE EXCESS PROFITS OF A PRIVATE FIRM.}

W. M. Blackwood \& Sons, Manufacturers.

Profit and Loss Account-Year ended December 3I, I9I7.

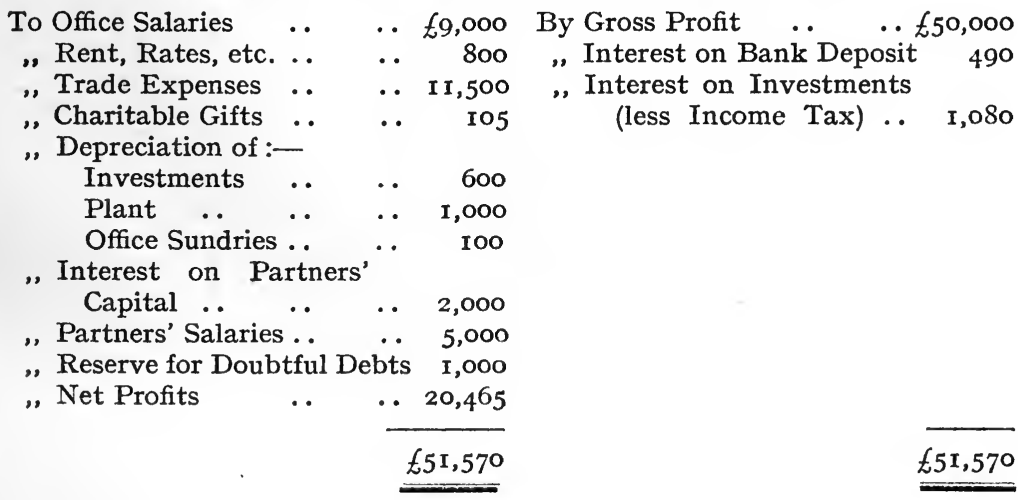

The profit of $£ 20,465$ would have to be adjusted by adding back charges which are inadmissible, and deducting profits derived from other sources than trade, thus :- 
Net Profit as per account .. $\quad \ldots \quad \ldots \quad \ldots \quad \ldots 20,465$ Add Charges inadmissible :

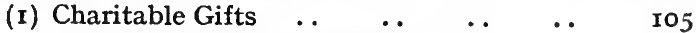

(2) Depreciation of Investments $\quad$. $\quad \ldots \quad 600$

(3) Depreciation of Plant . . $\quad$. $\quad \ldots \quad$ I,000

(4) Interest on Partners' Capital _. $\quad$. $\quad 2,000$

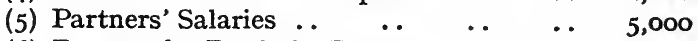

(6) Reserve for Doubtful Debts .. . . $\quad$ I,, 000

(7) Deduct Interest on Investments .. $£ 30,170$

$\overline{£ 29,090}$

Deduct Allowance for wear and tear of Plant.. 750

Profit for E.P.D. Purposes $\quad \ldots \quad \ldots \quad \quad \ldots \quad \overline{£ 28,340}$

I. Charitable Gifts: Subscriptions to war charities and the like are disallowed, but subscriptions to institutions directly benefiting the workpeople in the business assessed are allowed.

2. Depreciation of Investments : As the firm are manufacturers, making investments is not part of their regular business, and all losses, or profits, on the sale of investments should be excluded.

3. Depreciation of Plant: Although this is added back, an allowance for wear and tear will be made if renewals of plant are not charged against the profits.

4. Interest on Partners' Capital: This is charged for two reasons :-

(a) To ascertain what profit is earned after charging a reasonable amount for the use of the capital employed; and

(b) To adjust the rights of the partners as between themselves as regards the capital provided by them.

This item is, in fact, an appropriation of profits, and so must be added back.

5. Partners' Salaries: This charge is disallowed, as it is merely an adjustment of the rights of the partners between themselves.

6. Reserve for Doubtful Debts: Reserves are not allowed as a charge against the profits, but any debts ascertained to be bad and actually written off in the books as irrecoverable will be allowed. 
7. Income from Investments: There is no liability to Excess Profits Duty in respect of this item, and, in ascertaining the amount of the capital employed in the business, the capital value of the investments as it stands in the balance sheet will be excluded.

To complete the computation, let it be assumed that the PreWar Standard of the firm has already been agreed at $£ 20,000$; that the capital employed was increased on January I, I9I7, by $£ 5,000$; and that the profits in the first three accounting periods, adjusted in the same way as the profits of I9I7, were: $1914, £ \mathrm{r} 8,000$; I9I5, £I9,500; I9I6, £20,000; then the liability to duty will, in accordance with the formula given on p. 9, be found thus :-

Profits of fourth Account Period after adjustment $\quad . \quad \ldots \quad \ldots \quad \ldots \quad £ 28,340$
Deduct Interest at I I per cent. p.a. on $£ 5,000$ additional capital

$$
\text { employed }
$$

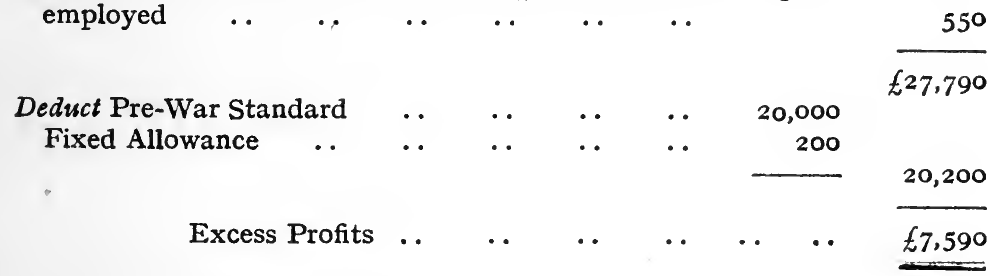

COMPUTATION OF DUTY PAYABLE.

\begin{tabular}{|c|c|c|c|c|c|c|c|}
\hline Year. & Profits. & P.W.S. & Deficiency. & Excess. & Rate. & Set Off. & Duty. \\
\hline 1914 & $\stackrel{£}{£}$ & $\begin{array}{c}£ \\
20,200\end{array}$ & $\underset{2,200}{€}$ & 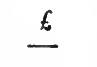 & $\begin{array}{c}\text { Per cent } \\
50\end{array}$ & $\underset{I, 100}{€}$ & $\underline{E}$ \\
\hline 1915 & 19,500 & ", & 700 & - & 60 & 420 & 一 \\
\hline r916 & 20,000 & ," & 200 & - & 60 & 120 & 一 \\
\hline 1917 & 27,790 & " & - & 7,590 & 80 & - & 6,072 \\
\hline
\end{tabular}

I,640

Net amount payable two months after assessment .. 4,432

$$
£ 6,072
$$

Nore.-Had the capital been reduced by $£ 5,000$ interest at 7 per cent. per annum would be added to the profits.

The adjustment for Excess Profits Duty purposes, of the profits of a limited company presents some features not found when dealing with the accounts of a private firm or sole trader. The following will serve as an example:- 


\section{COMPUTATION OF THE EXCESS PROFITS OF A LIMITED COMPANY.}

BartletT \& Co., LtD., Drapers.

Profit and Loss Account-Year ended December 3I, I9I7.

\begin{tabular}{|c|c|c|c|c|}
\hline To Salaries .. & . & - $£ 22,350$ & By Gross Profit ... & $\cdots £ \mathrm{r} 82,298$ \\
\hline ", Trade Expenses & $\ldots$ & . 35,000 & „, Transfer Fees.. & .. \\
\hline „, Advertising & .. & 30,000 & & \\
\hline "Bad Debts & . & $x, 600$ & & \\
\hline „Income Tax & . & 10,000 & & \\
\hline Depreciation of : & & & & \\
\hline Fixtures & .. & 500 & & \\
\hline Leases & .. & 1,000 & & \\
\hline Debenture Inter & est & 5,000 & & \\
\hline Managing Direct & tors' Sala- & & & \\
\hline & & 10,000 & & \\
\hline Net profit & - & 66,873 & & \\
\hline & & $£ 182,323$ & & $£ 182,323$ \\
\hline
\end{tabular}

Adjustment For E.P.D. Purposes.

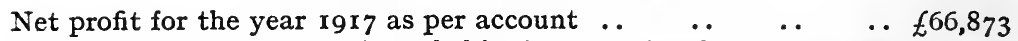

(I) Advertising: Amount, included in $£ 30,000$, distributed amongst

the public as prizes for subscribing to National War Bonds 5,000

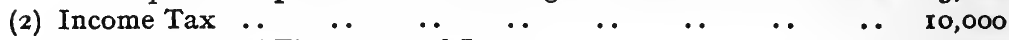

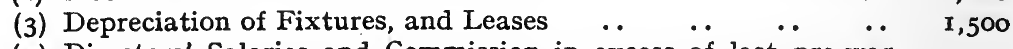

(4) Directors' Salaries and Commission in excess of last pre-war

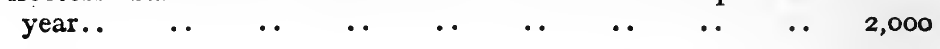

Profits for Excess Profits Duty purposes $\quad \ldots \quad \ldots \quad \ldots \quad \ldots \quad \ldots \quad £^{8} 8,373$

I. Although it is in the public interest to make the subscription to National War Bonds as attractive as possible, money prizes offered cannot be allowed to reduce the liability either to Excess Profits Duty or Income Tax.

2. Income Tax is an allocation of profits, and is disallowed both for Income Tax and Excess Profits Duty purposes.

3. Depreciation of fixtures is disallowed, but renewals may be debited against the profits. Depreciation of leases is disallowed, as this is regarded as a loss of capital.

4. The Fourth Schedule of the Finance (No. 2) Act, IgI5, Rule 5, provides that any deduction for " remuneration of directors, managers, and persons concerned in the management of the trade or business shall not, unless the Commissioners of Inland Revenue, owing to any special circumstances or to the fact that the remuneration of any managers or managing directors depends on the profits of the trade or business, otherwise direct, exceeds the sums allowed for those purposes in the last pre-war trade 
year." It was contended, on behalf of W. France, Fenwick \& Co., that this was not a discretionary provision, but that when the remuneration was based on profits the Revenue was compelled to allow the increased remuneration. The Divisional Court ruled that the paragraph merely imparted a discretion, and the Court of Appeal has recently sustained that judgment. Provision is also made by section 49 of the Finance Act, I9I6, not only for disallowing increases in remuneration of directors, managers, or persons concerned in the management of a business, but for recovering from them the duty paid on their behalf. In effect, the charge on the directors' or employees' excess is a separate assessment, so that the company's set-off under s. 38 (3) is not affected. For example:

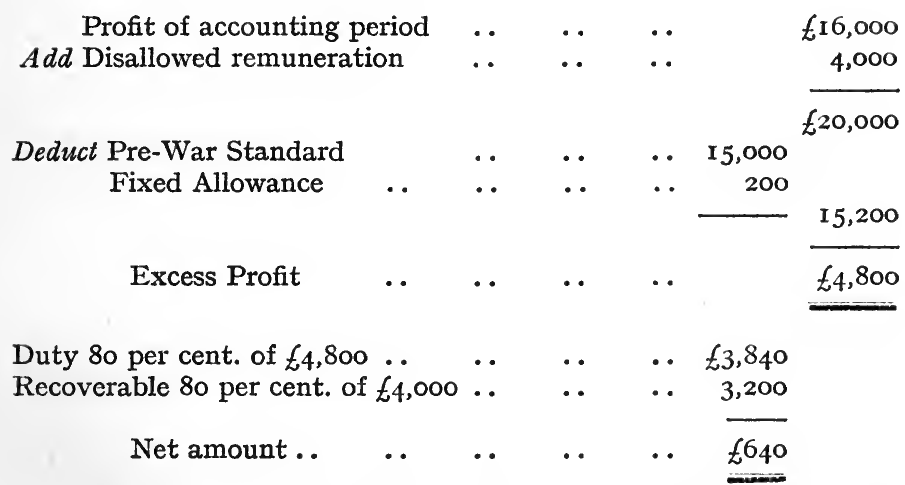

As will be seen from the table of "Alternative Methods of Computing the Pre-War Standard of Profits," on p. 9, oldestablished businesses which had lean years before the outbreak of war may claim to have their Pre-War Standard based on the average profits of the four best years out of six, instead of the average on the two best trade years out of three. In such cases it is usually the best plan to make the adjustments very carefully for the six years before deciding which are the best four to take, so as to obtain the highest average profit. After the lapse of a few years one is apt to forget that, perhaps five years back, some exceptional item was charged against the profits which it may be quite proper to add back for Excess Profits Duty purposes. 


\section{CHAPTER IV}

APPLICATIONS FOR MODIFICATIONS OF THE RULES OR FOR INCREASE in Statutory Percentages. Orders of Board of Referees increasing Statutory Percentages. Notices. Appeals.

7 He rules relating to the calculation of Excess Profits Duty are not, like the laws of the Medes and the Persians, absolutely unalterable. Under certain circumstances traders can apply (I) collectively and (2) individually for modifications in the rules (s. 42).

Traders may apply collectively to the Commissioners of Inland Revenue for an increase of the Statutory Percentage or the calculation of the Percentage Standard by reference to some factor other than the capital, or some additional factor, in the case of any class of trade or business in which the amount of capital actually employed is, owing to the nature of the business, small compared with the capital necessarily at stake (s. 42).

Application may also be made for an alteration of the PreWar Standard of Profits as respects capital employed for the purpose of the manufacture of War Materials or for Munitions Work, and which could not be expected to be remunerative, or wholly remunerative, except in time of war, in a business which has been wholly or mainly carried on for these purposes (s. 42).

The Commissioners of Inland Revenue have no power to decide such cases, but unless they are of opinion that the application is frivolous or vexatious, or relates to matters already decided by the Board of Referees, they must refer the case to the Board of Referees constituted by the Act. The Board may by Order, if they think fit, increase the Statutory Percentage, or alter the Percentage Standard for the class of trade or business concerned, or alter the Pre-War Standard of Profits as the case requires (s. 42).

It will be observed that these provisions apply to a class or subdivision of a trade or business, and not to an individual business, and the evidence upon which the Order will be made will depend on the average results of the class or subdivision taken collectively.

The principal considerations which affect applications are :- 
I. The fact that a considerable portion of the capital is represented by wasting assets.

2. The deferment of yield in the initial stages of the industry.

3. Extra risk to capital by reason of special circumstances, such as risk of loss, fluctuation in price or product, situation in a foreign country, fluctuation in exchanges, etc.

An excellent example of the advantage of collective action appears in the London Gazette of March I, I9I8, when an Order was published increasing the Statutory Percentage as regards the business of prospecting for, mining, and dressing tin ore and other minerals, in the United Kingdom, to 25 per cent. The Order was made on the application of the Cornish Chamber of Mines, acting on behalf of miners in Devon and Cornwall.

Numerous other Orders increasing the Statutory Percentage have been made by the Board of Referees. The following is a complete list up to date.

CAPITAL PERCENTAGES.

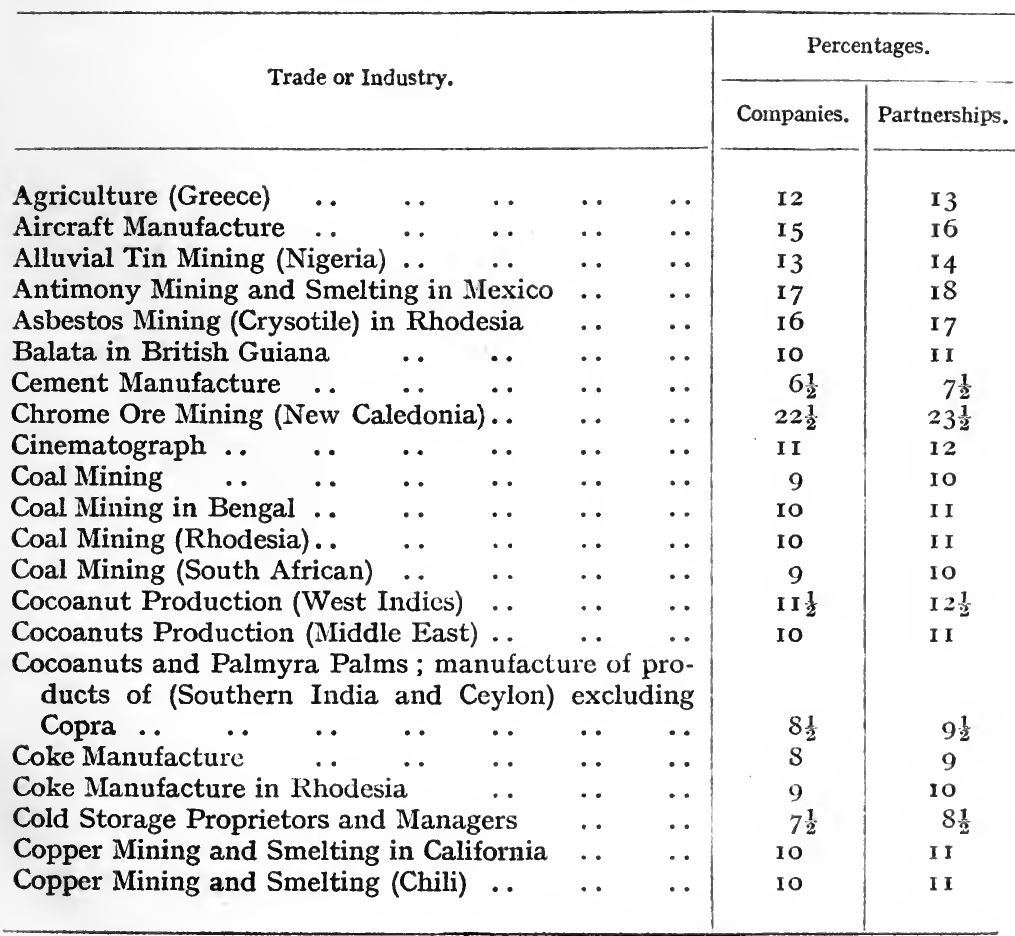




\section{CAPITAL PERCENTAGES-continued.}

\begin{tabular}{|c|c|c|c|c|c|c|}
\hline \multirow{2}{*}{\multicolumn{5}{|c|}{ Trade or Industry. }} & \multicolumn{2}{|c|}{ Percentages. } \\
\hline & & & & & \multirow{2}{*}{ Companies. } & \multirow{2}{*}{$\frac{\text { Partnerships. }}{16}$} \\
\hline Copper Mining (Rhodesia) & . & .. & . & $\cdots$ & & \\
\hline Daily Newspapers $\quad$.. & .. & .. & $\ldots$ & $\because$ & 8 & 9 \\
\hline Electric Cables Manufacture & . & .. & $\ldots$ & $\ldots$ & 7 & 8 \\
\hline Electric Supply (India).. & . & . & . & $\cdots$ & 7 & 8 \\
\hline Electric Supply (London) & . & . & $\cdots$ & $\cdots$ & 7 & 8 \\
\hline Electric Supply (Provinces) & . & . & $\cdots$ & $\cdots$ & $7 \frac{1}{2}$ & $8 \frac{1}{2}$ \\
\hline Electric Tramways (Cape Col & ony) & .. & $\cdots$ & $\cdots$ & $7 \frac{1}{2}$ & $8 \frac{\pi}{2}$ \\
\hline Electric Tramways (India) & . & . & . & $\cdots$ & 7 & 8 \\
\hline Electrical Trade.. & . & & $\ldots$ & $\ldots$ & 7 & 8 \\
\hline \multicolumn{7}{|c|}{ Electrical and Compressed Air Power, Supply of, in } \\
\hline Transvaal $\quad \ldots \quad \ldots$ & $\cdots$ & . & . & .. & 9 & Io \\
\hline Electrical Supply (Victoria) & . & . & . & .. & $7 \frac{1}{2}$ & $8 \frac{1}{2}$ \\
\hline Electrode Manufacture .. & . & . & . & .. & 6 & 7 \\
\hline Engineering (Bengal) $\ldots$ & .. & . & . & .. & 8 & 9 \\
\hline $\begin{array}{l}\text { Erinoid-Production from } \\
\text { chemical process of a hor } \\
\text { non-inflammable and non- }\end{array}$ & $\begin{array}{l}\text { Casei } \\
\text { n-like } \\
\text { condu }\end{array}$ & $\begin{array}{l}\text { by } p \\
\text { nater } \\
\text { ting }\end{array}$ & $\begin{array}{l}\text { ssurc } \\
\text { wh } \\
\ldots\end{array}$ & $\begin{array}{l}\text { ind } \\
\text { is }\end{array}$ & $7 \frac{1}{2}$ & $8 \frac{1}{2}$ \\
\hline Explosives & . & . & . & . & 8 & 9 \\
\hline \multicolumn{7}{|c|}{ Gold Mining in Columbia (excluding recovery of Gold } \\
\hline from alluvial working and & by $d$ & dging & . & . & 15 & 16 \\
\hline Gold Mining (India) $\quad \ldots$ & $\cdots$ & . & . & .. & $27 \frac{1}{2}$ & $28 \frac{1}{2}$ \\
\hline Gold Mining in Egypt and St & adan & . & . & .. & $27 \frac{1}{2}$ & $28 \frac{1}{2}$ \\
\hline Gold Mining (Rhodesia) & . & . & .. & .. & $22 \frac{1}{3}$ & $23 \frac{1}{2}$ \\
\hline Gold Mining in West Africa & - & . & . & .. & $22 \frac{1}{2}$ & $23 \frac{7}{2}$ \\
\hline Grecian Magnesite Miners & $\cdots$ & . & .. & .. & 10 & I I \\
\hline Hosiery .. & . & .. & .. & .. & 6 & 7 \\
\hline \multicolumn{7}{|c|}{ Indigo Growing and Manufacture (British India and } \\
\hline Native States) & . & . & .. & .. & 12 & 13 \\
\hline Iron and Steel Industries $(\mathrm{Be}$ & engal & . & .. & . & Io & I I \\
\hline Iron Ore Mining in Algeria & . & . & .. & .. & I 4 & 15 \\
\hline Jute Spinning (Bengal).. & $\ldots$ & . & $\ldots$ & .. & 7 & 8 \\
\hline Lead Mining (Western Austr & alia & . & .. & .. & 14 & 15 \\
\hline Magneto Manufacture .. & . & . & .. & .. & I I & I 2 \\
\hline Manganese Ore Mining in Gr & eat $\mathrm{H}$ & tain & .. & .. & I6 & I 7 \\
\hline Mangrove Bark (Borneo) & $\cdots$ & . & .. & . & Io & I I \\
\hline Marine Salvage $\ldots$ & $\cdots$ & . & .. & . & I5 & I6 \\
\hline Metalliferous Ores in Burma & . & . & . & . & $12 \frac{1}{2}$ & $13 \frac{1}{2}$ \\
\hline \multicolumn{5}{|c|}{ Metals and Alloys (for high-speed steel production) } & 12 & 13. \\
\hline Military Ornaments Manufac & ture & . & .. & . & $8 \frac{1}{2}$ & $9 \frac{1}{2}$ \\
\hline Motor Manufacturers .. & . & . & .. & .. & 7 & 8 \\
\hline Newspapers (Scotland) & . & . & .. & .. & 8 & 9 \\
\hline Nickel Mining in New Caledo & nia & . & .. & .. & 8 & 9 \\
\hline Nitrate Extracting and Refin & hing & nili) & .. & .. & 9 & Io \\
\hline Oil Production (Assam) & .. & .. & .. & .. & 8 & 9 \\
\hline Oil Production in Persia & .. & . & .. & $\cdots$ & I I & 12 \\
\hline Oil Production (Roumania) & .. & . & .. & $\ldots$ & $8 \frac{1}{2}$ & $9 \frac{1}{2}$ \\
\hline
\end{tabular}


CAPITAL PERCENTAGES-continued.

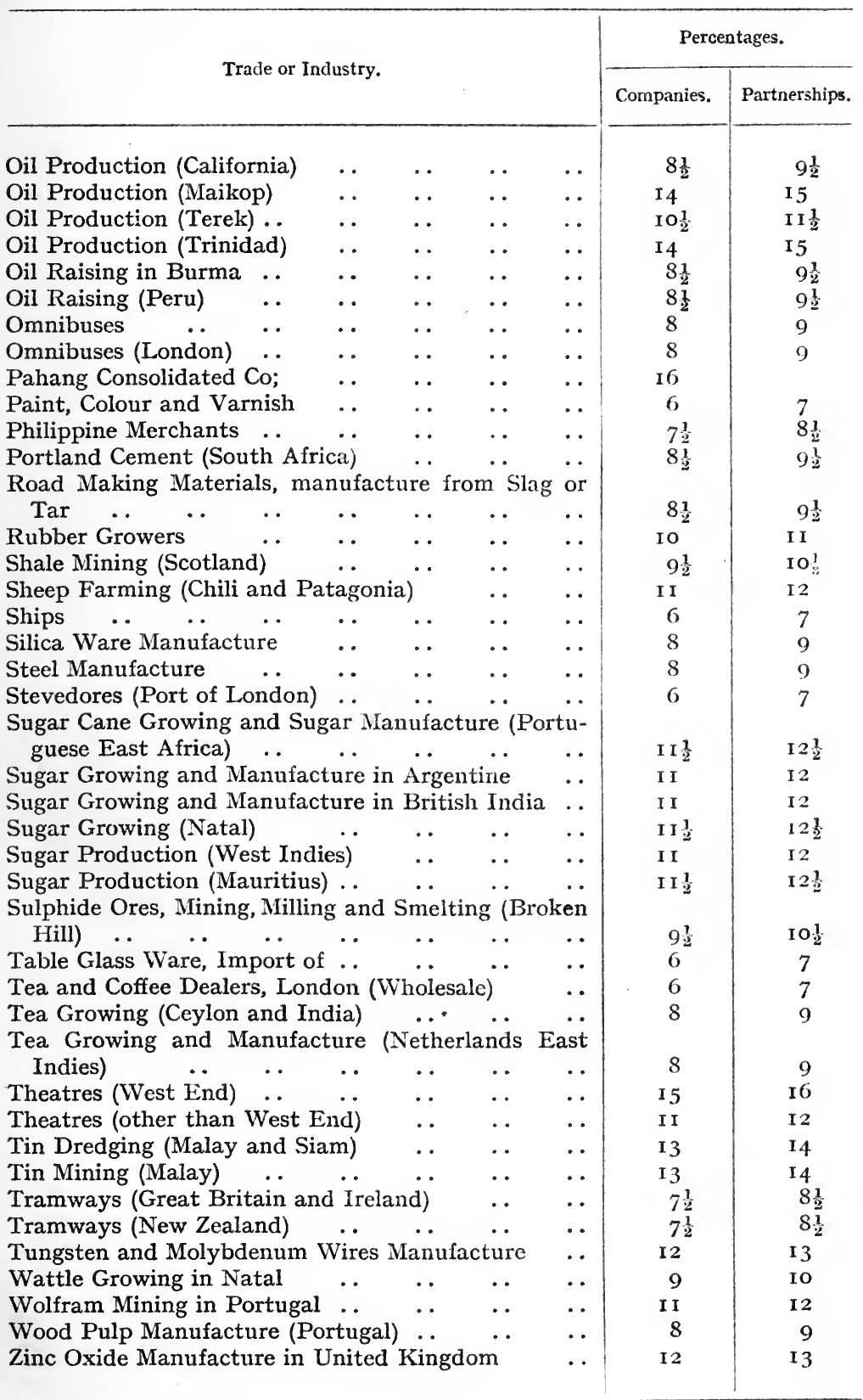


For accounting periods ending after December 3I, I9I6, the percentage for firms and sole proprietorships is increased by a further I per cent., and for all concerns an additional 3 per cent. is allowed for increased capital.

The Commissioners of Inland Revenue also have power, on the application of an individual taxpayer, to allow some modification of the rules set out in the Fourth Schedule of the Act of I9I5, provided the applications are made under the following circumstances :-

I. Owing to a change in the constitution of the firm.

2. Owing to the postponement or suspension, as a consequence of the present war, of renewals or repairs.

3. Owing to exceptional depreciation or obsolescence of assets employed in the trade or business, due to the present war.

4. Owing to the necessity, in connection with the present war, of providing plant which will not be wanted for the purpose of the trade or business after the termination of the war.

5. Owing to any other special circumstances specified in Regulations made by the Treasury. (Note.-The only Regulation at present made relates to depreciation of patents.)

If the Commissioners refuse to allow the modification asked for, or the applicant is dissatisfied with any modification allowed, he may require the Commissioners to refer the case to the Board of Referees.

The official forms and instructions as to procedure in making applications, whether collectively or individually, may be obtained on application to the Secretary, Commissioners of Inland Revenue, Somerset House, London, W.C.

\section{Artificial Transactions to Reduce Profits.}

It is important that no artificial transactions of any kind should be entered into so as to reduce profits. Section 44 (3) of the Finance (No. 2) Act, I9I5, is as follows:-

A person shall not, for the purpose of avoiding the payment of Excess Profits Duty, enter into any fictitious or artificial transaction or carry out any fictitious or artificial operation, and, if he has entered into any such transaction or carried out any such operation before the commencement of this Act, shall inform the Commissioners of Inland Revenue of the nature of the transaction or operation.

If any person acts in contravention of, or fails to comply with, this provision, he shall be liable on summary conviction to a fine not exceeding one hundred pounds. 


\section{Notices.}

It is the duty of every person chargeable to Excess Profits Duty to give notice to the Commissioners of Inland Revenue before the expiration of two months after the termination of any accounting period in respect of which he is chargeable. If he fails to give the required notice he is liable on conviction to a fine of $£$ roo, and a further penalty not exceeding $£$ Io a day during which the offence continues after conviction.

If in any case any person required by law to make a return fails to do so, or if the return made by him appears to the Commissioners of Inland Revenue to be incorrect or insufficient, the Commissioners may, without prejudice to the enforcement of any penalty which may have been incurred, make an assessment of Excess Profits Duty according to the best of their judgment.

\section{APPEALS.}

Any person dissatisfied with the amount of any assessment may at any time within thirty days from the date of the service of notice of assessment, or within such further time as the Commissioners of Inland Revenue may allow, give notice to the Surveyor of Taxes named in the notice of assessment of his intention to appeal against the amount of the assessment, and every such notice shall specify the grounds of appeal, and, in England, Scotland, and Wales, whether the appellant desires that the appeal shall be heard by the General Commissioners or the Special Commissioners when the duty is payable.

The duty assessed is payable two months after notice of assessment has been served on the taxpayer. Where it is difficult to pay the whole amount in one lump sum the Revenue will accept payment in two or more instalments without charging interest for the delay. National War Bonds which have been held by the taxpayer for six months will be accepted in payment of the duty, and due allowance will be made for interest accrued on the bonds. 


\section{FINANCE (No. 2) ACT, 1915}

\section{FOURTH SCHEDULE}

\section{Part I.-Computation of Profits}

I. THE profits shall be taken to be the actual profits arising in the accounting period; and the principle of computing profits by reference to any other year or an average of years shall not be followed.

2. The principle of the Income Tax Acts under which deductions are not allowed for interest on money borrowed for the purpose of the trade or business, or for rent, or royalties, or for other payments Income Tax on which is collected at the source (not being payments of dividends or payments for the distribution of profits), and under which profits or gains arising from lands, tenements, or hereditaments forming part of the assets of the trade or business are excluded shall not be followed.

3. Deductions for wear and tear or for any expenditure of a capital nature for renewals, or for the development of the trade or business or otherwise in respect of the trade or business, shall not be allowed except such as may be allowed under the Income Tax Acts, and if allowed shall be only of such amount as appears to the Commissioners of Inland Revenue to be reasonably and properly attributable to the year or accounting period.

4. Deductions shall not be allowed on account of the liability to pay, or the payment of, Income Tax or Excess Profits Duty, but a deduction shall be allowed (if not otherwise allowed by means of the adoption of the principle of the Income Tax Acts) for any sum which has been paid in respect of the profits on account of any Excess Profits Duty or similar duty imposed in any country outside the United Kingdom.

5. Any deduction allowed for the remuneration of directors, managers, and persons concerned in the management of the trade or business shall not, unless the Commissioners of Inland Revenue, owing to any special circumstances or to the fact that the remuneration of any managers or managing directors depends on the profits of the trade or business, otherwise direct, exceed the sums allowed for those purposes in the last pre-war trade year or a proportionate part thereof as the case requires, and no deduction shall be allowed in respect of any transaction or operation of any nature, where it appears, or to the extent to which it appears, that the transaction or operation has artificially reduced the amount to be taken 
as the amount of the profits of the trade or business for the purposes of this Act.

6. Where any company, either in its own name or that of a nominee, owns the whole of the ordinary capital of any other company carrying on the same trade or business or so much of that capital as under the general law a single shareholder can legally own, the provisions of Part III of this Act as to Excess Profits Duty and the Pre-War Standard of Profits shall apply as if that other company were a branch of the first-named company, and the profits of the two companies shall not be separately assessed.

7. Where in the case of any trade or business--

(a) The percentage standard is adopted as the Pre-War Standard of Profits ; and

(b) The net result of the trade or business during the three last pre-war trade years has shown a loss; and

(c) Any part of the profits has been applied in extinction of that loss ;

then in estimating the profits a deduction shall be allowed equal to the amount of profits so applied.

8. In estimating the profits no account shall be taken of income received from investments except in the case of life assurance businesses and businesses where the principal business consists of the making of investments. Where account is taken of any such income-

(a) Any variation in the value of any of those investments which appears to the Commissioners of Inland Revenue not to be due to a variation in profits shall also be taken into account; and

(b) Where the income has been derived from profits in respect of which any payment or repayment of Excess Profits Duty has been made under this Act, such deduction or addition shall be made in computing the profits as will make proper allowance for that payment or repayment of duty.

9. In computing the total profits of a local authority from any trades or businesses carried on by that authority the total amount which is required to be raised by them, out of the rates or otherwise, for sinking fund purposes in connection with those trades or businesses shall be allowed as a deduction.

Io. In the case of societies registered under the Industrial 
and Provident Societies Acts the Excess Profits Duty shall be on the sum by which the profits per member for the accounting charged period (including any surplus arising from transactions with members) exceed the like profits per member in the pre-war trade year or average of years taken as the basis of computation for the purpose of the Pre-War Standard of Profits, multiplied by the number of members in the accounting period.

II. In the case of any contract extending beyond one accounting period from the date of its commencement to the completion thereof and only partially performed in any accounting period there shall (unless the Commissioners of Inland Revenue, owing to any special circumstances, otherwise direct) be attributed to each of the accounting periods in which such contract was partially performed, such proportion of the entire profits or loss or estimated profits or loss in respect of the complete performance of the contract as shall be properly attributable to such accounting periods respectively, having regard to the extent to which the contract was performed in such periods.

\section{PART II.-PRE-WAR Standard.}

I. The profits of any pre-war trade year shall be computed on the same principles and subject to the same provisions as the profits of the accounting period are computed.

2. Where the accounting period for which the Excess Profits Duty is to be assessed is less than a year, the amount of the PreWar Standard of Profits shall be proportionately reduced.

3. Where it is shown to the satisfaction of the Commissioners of Inland Revenue in the case of any trade or business that the last three pre-war trade years have been years of abnormal depression, any four of the last six pre-war trade years may be substituted for the purposes of the Pre-War Standard of Profits for any two of the three last pre-war trade years.

The three last pre-war trade years shall not be considered as years of abnormal depression unless the average profits of those years have been at least twenty-five per cent. lower than the average profits of the preceding three years.

4. Where owing to the recent commencement of a trade or business there have not been three pre-war trade years, but there have been two pre-war trade years, the Pre-War Standard of Profits shall be taken to be the amount of the profits arising from the trade or business on the average of those two years or, at the option of the taxpayer, the profits arising from the trade or business during the last of those two years, and where there have not been 
two pre-war trade years, but there has been one pre-war trade year, the Pre-War Standard of Profits shall be taken to be the profits arising from the trade or business during that year; and where there has not been one pre-war trade year, the Pre-War Standard of Profits shall be taken to be the statutory percentage on the average amount of capital employed in the trade or business during the accounting period.

Where the trade or business is an agency or business of a nature involving capital of a comparatively small amount, the Pre-War Standard of Profits shall be computed by reference to the profits arising from any trade, business, office, employment, or profession of any sort, whether liable to Excess Profits Duty or not, carried on by the agent or other person before his new trade or business commenced as if it was the same trade or business; but only to the extent to which the income from the former trade, business, office, employment, or profession has been diminished.

5. Where since the commencement of the last three pre-war trade years a trade or business has changed ownership, the provisions of this Part of this Schedule shall apply as if a new trade or business had been commenced on the change of ownership, except in cases when the taxpayer makes an application that the provisions of Part III of this Act and this Schedule should apply as if the trade or business had not changed ownership, but in that case such modifications (if any) shall be made in the application of this Schedule as may be necessary to make the basis on which the profits standard is computed the same as that on which the profits of the accounting period are computed.

6 . It is hereby declared that, where any business or trade is confined to the management of any particular assets, but power exists to substitute other assets for those particular assets or any of them, such a substitution shall not be deemed, for the purposes of Part III of this Act, to constitute a change of ownership of the business; but, where any such substitution has been carried out by the sale of assets and the purchase of other assets, the capital of the trade or business shall be taken to be increased or decreased, as the case may be, only by the amount of the difference between the price of the assets purchased and the price obtained for the assets sold, and the capital representing the assets purchased shall be estimated on the same basis for all the purposes of Part III of this Act.

\section{PART III.-CAPITAL.}

I. The amount of the capital of a trade or business shall, so far as it does not consist of money, be taken to be- 
(a) So far as it consists of assets acquired by purchase, the price at which those assets were acquired, subject to any proper deductions for wear and tear or replacement, or for unpaid purchase money; and

(b) So far as it consists of assets being debts due to the trade or business, the nominal amount of those debts subject to any reduction which has been allowed in respect of those debts for Income Tax purposes; and

(c) So far as it consists of any other assets which have not been acquired by purchase, the value of the assets at the time when they became assets of the trade or business, subject to any proper deductions for wear and tear or replacement.

Nothing in this Part of this Schedule shall prevent accumulated profits employed in the business being treated as capital.

2. Any capital the income on which is not taken into account for the purposes of Part I of this Schedule, and any borrowed money or debts, shall be deducted in computing the amount of capital for the purposes of Part III of this Act.

3. Where any asset has been paid for otherwise than in cash, the cost price of that asset shall be taken to be the value of the consideration at the time the asset was acquired, but where a trade or business has been converted into a company and the shares in the company are wholly or mainly held by the person who was owner of the trade or business, no value shall be attached to those shares so far as they are represented by goodwill or otherwise than by material assets of the company unless the Commissioners of Inland Revenue in special circumstances otherwise direct. Patents and secret processes shall be deemed to be material assets.

Valuation of Stocks after the Termination of the War.

The Board of Inland Revenue are prepared to adopt the following modifications of the general principle that stocks should be valued at cost price or market value, whichever is the lower.

I. A period of two years will be allowed after the termination of the war in which to ascertain by actual realization the value of the stock appearing in the account at the end of the last accounting period, and an allowance made from the profits of that period for any difference between the valuation and the sum realised.

The loss (if any) on only. such stocks as were in hand at the end of the last accounting period will be brought into the adjustment, but the whole of such stocks, not individual parcels selected by the taxpayer, must be considered. 
The necessary sanction for this modification of general principles will be given by a regulation under section 40 , subsection 3 , of the Finance (No. 2) Act, I9I5.

2. Certain classes of industry require to keep stocks of raw or semi-manufactured goods for the purposes of manufacturing processes, and these goods are frequently of such an imperishable character that a minimum quantity required for a business could be held untouched for a long period.

Accordingly, any class of trade-

(a) Which requires for its manufacturing processes to keep such stocks, and

(b) In which a recognized practice has obtained of valuing a constant quantity at a fixed price,

the Board of Inland Revenue are prepared to recognize the practice.

The Board of Inland Revenue would regard goods as imperishable which are of sufficient durability to last without material deterioration during a period equal to the length of the war.

Any individual member of the class who has not adopted the method in his business may be allowed to do so for the purposes of Excess Profits Duty, but may not claim as the constant quantity of stock so valued a greater quantity than the minimum amount held at any stocktaking in the three pre-war trade years.

Where a claim is made that an industry should be brought within this concession the Board of Inland Revenue are prepared to receive representations and to consider evidence as to the existence of a material body of such practice in the industry and as to the character of the stocks to which it is claimed the method should be applied, with a view to securing the uniform treatment of all members of the industry.

The balance of stock above the minimum quantity in cases falling under this modification of the general principle is to be treated as in (I).

3. Profits derived from sales which reduce stock below the particular minimum or constant quantity adopted for any business are not the less trading profits. Where, however, a raw material is associated with plant in a manufacturing process (e.g. metal kept to a constant level in galvanizing baths), the Board of Inland Revenue will consider a claim under section 40 (3) of the Finance (No. 2) Act, I9I5, that it is akin to a capital asset, like plant, which has been exceptionally depreciated (by depletion) or of which the renewal has been postponed.

4. Where in an industry or as respects a class of stock to which the foregoing (2) does not apply, the owner of a business 
has taken a quantity of stock at a base price, the stock will fall to be valued during the periods of liability at cost or market value, whichever is the lower; but from the final valuation (on that basis) there will be allowed a deduction of a sum (in pounds sterling) equal to the original difference (at the end of the standard period) between the valuation on the base method and a valuation on the cost or market value method. Alternatively, the first stock valuation may be revised and put upon the general basis of cost or market value, when the madification outlined in (I) will apply.

Special Allowances for Obsolescence of Assets employed DURING THE WAR.

For Income Tax purposes, allowances are restricted to the diminution in value due to wear and tear and obsolescence of plant and machinery. For Excess Profits Duty purposes, on the other hand, further allowances are admissible; section 40 (3) Finance (No. 2) Act, I9I5, provides for

\section{Special Relief-}

(a) In respect of the postponement or suspension, as a consequence of the present war, of renewals or repairs ;

(b) Exceptional depreciation or obsolescence of assets employed in the business due to the present war: and

(c) The necessity in connection with the war of providing plant which will not be wanted for the purposes of the trade or business after the termination of the war.

3. These allowances extend to any material assets employed in a business, and not merely to machinery and plant. Where these assets have been constructed or acquired during the war at an inflated price and will sink to a lower level of value, or even to scrap value, at the end of the war, full relief can be claimed. The measure of the allowance to be made in respect to such assets will be the difference between cost and post-war value. An allowance of the like nature is, of course, applicable also to assets in use before the war, the value of which has fallen owing to war causes. The measure of the allowances in such cases is the difference between the value of the assets (depreciated or written down for wear and tear) at the date when liability to Excess Profits Duty began and their post-war value.

NotE.-In the case of Controlled Establishments the Income Tax allowance for wear and tear has been temporarily extended to include deductions for " exceptional depreciation or obsolescence of buildings, plant or machinery." 


\section{How SYSTEM Will Help YOU I N Y UR B US I N ES S}

C YSTEM, the Magazine of Business, tells you of literally 1 hundreds of time and labour-saving ideas and methods. It describes practical ways, simple in appearance but really vital, for organizing every item of your day's work and every branch of your business, thus enabling you to do more in the same time with far less labour, less worry, and more profit.

The purpose of SYSTEM is to seek out for you the most successful methods and systems in actual use to-day, and so to describe their operations and principles that you can make use of them or adapt them in your business.

Every month SYSTEM brings you latest methods and devices to save time and labour,

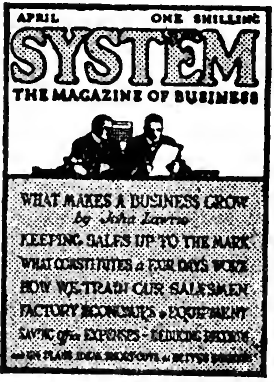
cut costs and reduce expenses. It tells the plans that have actually increased output, raised efficiency, and built up bigger businesses. It explains the latest methods for advertising and selling, finding new markets, and getting more trade.

It covers the whole field of business. The ideas, methods, and plans it describes are not theory; they are practical, drawn from the actual experience of successful business men in all branches of business.

Whatever business you are in, whatever position you hold, SYSTEM will help you to do more and to make more. No situation will find you unprepared if you make use of what SYSTEM brings you each month. Every issue of the Magazine is full of business suggestions for you, ready and waiting to be applied to your own work and business.

\section{$1 / 6$ a Copy.}

15 - a Year.

\section{A. W. SHAW CO. LTD.} 43-44 SHOE LANE, LONDON, E.C. 4. 



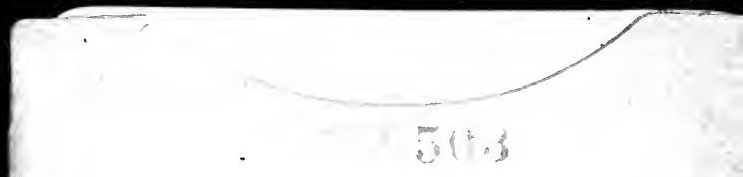

UNIVERSITY OF CALIFORNIA LIBRARY 
